\title{
Pela Dan Gandong Culture As Basic of A Network Formation For Poverty Alleviation In The Village
}

\author{
Elsina Titaley \\ Postgraduate, Department of Sociology, Faculty of Social and Political Sciences, \\ Brawijaya University, Malang, Indonesia \\ Department of Sociology, Faculty of Social and Political Sciences, \\ Pattimura University, Ambon, Indonesia \\ Sanggar Kanto \\ Department of Sociology, Faculty of Social and Political Sciences, \\ Universitas Brawijaya, Malang, Indonesia \\ Darsono Wisadirana \\ Department of Sociology, Faculty of Social and Political Sciences, \\ Universitas Brawijaya, Malang, Indonesia \\ Mardiyono \\ Department of Sociology, Faculty of Social and Political Sciences, \\ Universitas Brawijaya, Malang, Indonesia
}

\begin{abstract}
Poverty is remaining a major topic in the world community in the recent years. Therefore, it is needed a good concept in reducing poverty. The new concept offered in the context of indigenous peoples is pela and gandong culture which is a strong attribute in Moluccas poverty alleviation. Pela and gandong have existed since ancestral times and have remained guarded to this day. This concept is built on the basis that pela and gandong is a local community culture that helps each other to help one community with another. Life by helping each other is obligatory, not based on coercion but naturally. If this concept is effectively implemented it will contribute to poverty alleviation. The purpose of this study is to analyze the pela and gandong culture as a basis of network to eradicate rural poverty in Lomoli Village. This research is something new that is rarely studied in the context of indigenous peoples. The research sites selected is Lumoli village, which is still thick with pela and gandong concept. The implications of this research are to provide new resolutions to communities and governments in the pela and gandong context as a good foundation for building strong indigenous people in alleviating rural poverty
\end{abstract}

Keywords: Poverty Alleviation, Indigenous Peoples, Pela, Gandong.

\section{INTRODUCTION}

The problem of poverty in Indonesia became the first concern of President of Seokarno to Joko Widodo. Recalling the Age of President Seoharto, Indonesia was known as the State of rice granaries and one of the world's largest rice exporters of the 1960s (Roling \& van de Fliert, 1994; Booth, 1998). The people live in prosperous, serene and harmony with each other. The Indonesian government's efforts to overcome poverty have been done since the New Order era. As a result, during the years 1976-1996, the poverty rate in Indonesia declined significantly from $40 \%$ to $11 \%$ at the beginning of Repelita V (Mubyarto, 2003). The important note is not released from the success achieved by the State in implementing various kinds of economic development programs. For three decades, the Indonesian economy grew at an 
average of above 7\% per year (Purwanto, 2007). The success of the State of Indonesia in carrying out economic development and reducing poverty is then received much praise from the world community. The World Bank (1993) report entitled "The East Asian Miracle", places the Republic of Indonesia into one of Asia's tigers on "The High Performing Asian Economies (HPAEs)" parallel to South Korea, Taiwan, Thailand, Malaysia and Singapore .

The joy that did not last so long, where the World Bank released its report, stated that the great economic crisis had hit Indonesia in mid 1997. This crisis began with the problem of rupiah exchange rate against the US dollar. It is called as monetary crisis that is triggered by the fall of the Thai currency, Bath. Unexpectedly, the monetary crisis that is difficult to control by the government then triggered the emergence of political action that was colored by the fall of the New Order regime (Aspinall \& Mietzner, 2007; Tatyzo, 2011, Tan 2012). Like a blowing balloon, this philosophy is similar to the State of Indonesia. The monetary crisis then enlarged and became the trigger so that the occurrence of other crises. Hurricane storms that exist in the form of monetary crisis then cause Indonesia really fall and helpless. This can be seen with the separation of East Timor from Indonesia on October 19, 1999 (Dupont, 2000, Moxham \& Carapic, 2013; Leach \& Wood, 2014). The emergence of a conspiracy that spurred ethnic and religious conflicts in regions in Indonesia such as the Moluccas conflict in 1999 in Moluccas (Waileruny, 2010, Al Qurtuby, 2013, Colombijn, 2018, Matesan, 2018), North Moluccas (1999) (Wilson, 2015; Duncan, 2016), Sambas (19 February to Mey 1999) \& Poso (December 24, 1998 to 2007 (Schulze, 2017).

These conflicts have made people poor (Goss, 200; Sarkar \& Sengupta, 2016), which is represented by loss of people's wealth. It also took a long time to build government and rural infrastructure. This can be seen in the Moluccas conflict in general and more specifically Seram Island (Pessireron et al, 2017). People remain living in disharmony situation. For example, such a beautiful life of Christians and Muslims who used to live in one village was annihilated because of the political interests of the conspiracy (Al Qurtuby, 2007). The people of Moluccas, especially the Ambon island, Lease and the Seram island, known as the Golden City or known as the world trade city that produced clove and nutmeg (Hagerdal, 2015, Stott, 2017), became extinct due to the burning of land in 1999. Rural people who hope from crops become poor because of land fires. Therefore, it took time to plant up to get the cloves and nutmeg.

Government and related parties have done many efforts to alleviate the poverty problem, but its results are futile. Various poverty theories have been generated by various experts, and have been used by various countries and international organizations such as UNICEF, which is an important part of the (UN), but poverty rates still exist and fluctuate. It is clear that most of the rural areas living are still in poverty status. One of them is Lumoli Village, in Seram Island, Moluccas. Therefore, a good concept is needed in solving existing problems (Chen et al., 2011). One of the concepts offered for poverty alleviation of island communities is pela and gandong culture as the basis for networking for the eradication of rural poverty. This is one of the new concepts offeed for indigenous peoples in Moluccas and even in other areas that still follow thick customs.

Pela is an ancestral agreement made between two or more custom fellowships because of an event. The covenant (Pela) takes place between people who initially have no attachment, but commit themselves to the covenant and are bond in custom because of an event. After the pela tied, they consider themselves to be brothers of one of those bond to the pela who must live in mutual help, love one another, and so on. Another culture, Gandong, is a typical Moluccas people who derive from one mother's womb. Therefore, gandong is very different from pela, because there is no specific agreement between those who have a familial relationship (Lokollo 
(1997, Sahusilawane, 2004). They have soul and spirit to help each other naturally without any coercion in facing various problems both in difficult and happy as gandong in the bonds of brother and sister who came from one mother's womb. It is not limited by different body or physical, because it seemed as spiritual calling. By the concept of pela and gandong, Moluccas offered life of helping one another in the philosophy of sago salempeng in patang dua that means happy and difficult life must be felt together in the fraternity (Pattiselanno, 1999, Soegijono, 2015). If this concept is executed effectively then the poverty rate is reduced in Moluccas.

Lumoli community as a traditional village also holds Pela and Gandong relationship with the surrounding community. For example pela relationship between Lumoli Village with Kaibobu Village, between Lumoli Village and Buano Village and a gandong relationship between Lumoli Village with Desa Eti, and Desa Hulu. This brotherly relationship has been established since ancestral times. So it is passed down to the present generation. If this agreement is violated then there is a disaster for those who violate. For example, the Village suffered from disasters and natural disasters. Pela and gandong network of Lumoli society always held so that the society live in the way of helping each other.

Concerning the development of indigenous peoples in Moluccas, especially in Lumoli Village, Titahelu et al., 2015 explains that building indigenous peoples can be based on the potential of custom as an internal strength of society. The problem is now how and how far the local wisdom can survive and adjust to the present era. Thus, we certainly agree that the local wisdom that emanates from the cultural values of local communities remains a powerful force to mobilize the local community, but the main thing is to involve all the parties that are in synergy so that the local wisdom can reach its maximum function. Based on the explanation above, the purpose of this study is to analyze the complete culture of Pela and Gandong as the basic of Network Formation for Poverty Alleviation in Lomoli Village.

\section{Context of Indigenous People in Moluccas}

Indigenous peoples in Moluccas have various cultural values embodied in various local wisdom possessed as a basis for survival (Kaartinen, 2014). Indigenous peoples consider that the value of culture that becomes local wisdom where it is their existence and identity is highly appreciated and upheld, thus encouraging them to always boast and maintain it. Prior to the introduction of the celestial religion (Islam and Christianity) in Moluccas, indigenous peoples in Moluccas thought that culture was a belief that became a religion, so that although there is appreciation and treatment that is generally considered wrong by society (eg the treatment of women because they are considered low and dirty at the time of having their periods or giving birth so that they must be expelled from their homes and allowed to live alone), they (indigenous peoples, including women) accept it and carry it out gladly without burden because it is considered a religious obligation that must be lived. They believe that in violation of the provisions it will result in sin and sanctions not only to the perpetrators but also to the entire community of fellowship members. After the entry of the celestial religion followed by the development of science and technology, the community became aware and conscious that there has been a very big change that has occurred separation between cultures considered good by society, accepted as a result of copyrights or human works that must be maintained, the values in which can serve as guidelines for misbehavior are abandoned and only become records or stories by that society, while the teachings and values of religion come from God (Adam, 2008).

Of the cultural values possessed by the good Moluccas community, some are accepted as models to build cross-tribal, religious, and fraternal relationships. Moluccas conflicts resulting 
from political conspiracies resulting in so many human and material sacrifices, can be resolved with awareness of the cultural values of pela and gandong. On the contrary, to build a dignified human life, there are also cultural values of indigenous peoples that encourage or facilitate it. In short, the cultural values of indigenous peoples in Moluccas have strong spirituality for human development as well as in the effort to eradicate poverty for the welfare of prosperous people.

\section{Pela Culture}

Pela is an indigenous agreement committed between two or more indigenous peoples because of an event. Pela occurs between societies or communities that initially have no attachment, but because of an event then they commit themselves in agreement and custom bond. After the bond in pela, they only consider themselves as brothers that must live mutually by helping each other, love each other and so forth. The practice of pela in indigenous peoples has entered a deep mental dimension and sense of community value. The treatment seemed deeper than siblings. Indigenous peoples uphold the values tin Pela by customary rituals performed in the agreement process and in repetitive activities of pela correctly. If there is a violation of the pela agreement, it is believed by the public that there will be sanctions befall the community. Because of that reason, perpetrators who violate the culture should be immediately sanctioned (customary punishment) in order to punishment of breaking pela culture will not befall all members of the community. Indigenous peoples in Moluccas consider that persons in the indigenous peoples' association are not independent but are an integral part of an indigenous society in which individuals exist. We can see today that the fanaticism of the Moluccans against their land of origin is so strong, and conversely the sense of community alliances with the children of the land's children is so strong (although they have wandered long enough), as a proof of the integrity of the relationship between individual and indigenous peoples. Customary sanctions (including sanctions against pela violations) between one land and another. Sanctions concerning this pela are usually imposed on the offender after a deliberation of the peoples (in this case the people who are considered to be older) who owns pela, but there are also only from the people of the customary land where the person resides or originated.

The definition of pela delivered by some experts, among others, by Tanamal (1985) argues that:

One of bond form of family and fraternities that remain on guard to this day. Pela term is considered less clear when viewed in terms of the language of the land or indigenous language that is in Moluccas. For example, Patasiwa community in West Seram known pela-pela term means the sign, symbol or picture painted on the limbs with patterns and shapes that have meaning or certain message. It has also become a symbol of the unity of one group. The term pela in fact refers to the bond of unity and brotherhood between two or more Christian lands or Islamic lands as well as between Islamic and Christian lands.

Lestaluhu (Mollucan Historian from Central Moluccas) in a paper submitted in the Forum Discussion Towards New Moluccas After the Riot in 2002 argued that "Pela as the glue of harmony of the people of Moluccas". Another concept is that pela is a very strong social order of Moluccas society that has been taught by ancestors since long ago and has been preserved from generation to generation until now regardless of the differences of society, whether in the form of cultural, social and religious differences (Uneputty, 1996). The conclusion drawn from the pela concept is a bond or covenant or glue made between two or more groups of indigenous peoples. 
One of the key informants on behalf of Alexander Laturake who was a member of saniri but now has died argues that:

Pela is a binding relationship between a land and caused by many things. The Lumoli community defines pela as a loving relationship between two or more within the indigenous community.

The process of pela occurrence, in indigenous communities is very different, such as war, disasters and some are occurred due to economic needs, especially food and other needs. By the entry of Arab traders who teach Islam, then followed by the Portuguese who teach Christianity Catholic and Dutch who teach Protestant Christianity, certainly resulted in conflict among indigenous people of Moluccas. Especially with the devide et impera politic conducted by the Dutch against the natives. After an agreement to make peace, then they perform the ceremony with a promise. This promise is reinforced by an oath according to the belief that it has. Promise function is as a provision that must be carried out for generations. Pela that occurs due to natural disasters, emerges after the help of one party that save the victim from the death or other difficulties because of the disaster. After that both parties bind the promise in pela form to help each other up to the descendants. While pela that occurs due to economic needs, just emerged after the existence of blockades by the Dutch against the economic potentials to weaken the citizen struggle against the Dutch. Because of economic difficulties (food) then between the land is looking for relationships with other lands to obtain food aid. More is done in the lands on the island of Ambon and Lease with the lands on the island of Seram. This relationship is then institutionalized in pela bonds. Everything is done with an oath to be obeyed from generation to generation. There are several types of pela that exist, depend on the tool of the ceremony that is done pela affirmation. If the oath is done by drinking blood, then pela relationship is called pela darah. The way that is done is each of the blood from one of his limbs (finger or hand) poured into a place. The blood container is usually a coconut shell. After mixing with a little water or a regional specialty drinks such as sageru (tuak) or sopi, then drink together as a symbol of fellowship such as blood and flesh. If the oath is done with the betel and areca together, then pela is called pela tampa sirih (place of betel). Betel, areca and lime are put in place of betel, then all who take the oath in that place as a symbol of fellowship. Meanwhile, when pela was done on the rock, the pela is called pela batu karang.

By pela ceremony performed, each party who is bound in the bond feels compelled and willing to sacrifice for the benefit and happiness of the other parties. This is considered positive because it produces useful activities. Differences in religion, islands or others do not make them separate, but on the other hand pela passes the boundaries of religion, island boundaries and so on to overcome the various needs of life, including religious needs. The church building that was built, is not the responsibility of those who are Christians and vice versa, the construction of the mosque is not the responsibility of those who are Muslims, but the responsibility of the Moluccas (Islam-Christian). Therefore, when understanding the Moluccas religious philosophy, the government's program of interfaith harmony efforts is not needed to be applied in Moluccas, since it has been done since ancestors and has become a culturallyobeyed cultural value. The inter-religious life in the Moluccas should be an example to build harmony among religious communities in Indonesia as well as in multi-religious people countries. Inter-religious relations in Moluccas have passed a tough test, as a result of social conflict in Moluccas over the conspiracy.

The size or magnitude of the load impinged affects the nature of the pela agreement being built. If the burden is a war that caused the victim then there is an effort to solve it, the pela bond is done is a pela keras (hard pela). The same thing if there is help done in war or disaster 
that threatens safety. The oath bonds performed on this pela keras bond, followed by drinking blood, the blood of a few drops taken from the fingers of each war leader (kapitan) then placed on a container then mixed with sopi, or saguer (sageru) and then drunk by each kapitan followed by the children, followed by eating betel and areca. After this oath is done, then between them there has been a relationship even they consider each other like brothers themselves, so that among them can not marry each other, should not cheat or deny each other, but all they have to do is to help each other and complement.

If the load is not heavy, the pela bond is pela lunak (pela soft), ie the oath bond is not followed by drinking blood, but only by eating betel and areca. After the oath is done, then between them there has been a relationship and they even consider each other like brothers, but among them can marry each other. They should help and complement each other. Indigenous peoples think that in spirituality, this pela bond has the power to punish those who break the bond. For that, in doing something that becomes pela obligation, they do it with joy without burden.

The Lumoli community has links with the Kaibobu community in a pela bond. The pela bond between the people of Lumoli and Kaibobu is preceded by the war between the two who took their lives. After the killing, there is an attempt to resolve it followed by taking an oath and drinking blood. For that pela is called pela hard. The informants did not know when the oath was done, but the only thing he knows is that the bond had been done since ancient times.

When this research was conducted, the people of Lumoli land while building a church. In the development, they get help from Kaibobu people, so they feel no need to get help from the Kaibobu lands again. In addition to the help given, they will greet each other by saying "pela" when meeting each other in their daily activities. Besides the Kaibobu land as Pela there is also Buano land that became Pela. Thus, Alexander Laturake, Frans Matita, Edoard Latures as the customary elders of Lumoli land stated that should contact Buano to inform that they are building a parmanent church. The key informant believe that Buano people will be happy to help because it is an obligation for them even though they are Muslims and only get a notification without asking to help. Pela culture is a good bond for indigenous people in Moluccas.

From the description, it appears that the bonds or pela relations in indigenous peoples, have a high spiritual strength of communion and mutual support from those in the bond. Such bond or relationships as social capital to be a very effective source of power in order to overcome common problems, including in this case the poverty problems experienced by either party. The power of this spirituality does not apply for a moment, but continues to pass through the next generations, for it must be spoken of as a guide for the next generation. Nevertheless, the value of pela culture can be eroded as a result of the power of society too weak in the facing change with all its consequences. If there is no strengthening of society, various changes can affect the beautiful relationships.

Pela case that became bonds, for example, an event hapenned in 2015. It is in the space of West Seram Regional House of Representatives. One of Kaibobu residents who are members of Regional People's Representative Assembly (DPRD) of regency, conduct emotional actions and difficult to overcome by many people. DPRD's member have issued threatening words to fight with one of the head of departement in regency. The member of the DPRD is the brother of West Seram Regent. At that moment there was a Lumoli resident, by not speaking, just holding the hand of the legislator then taking him out of the room. They greet each other, admonish and counsel pela brothers who are members of parliament, so the situation could be under control. 


\section{Gandong}

Gandong is the land language of the people of Moluccas which refers to the womb, the brother and sister who come from one mother's womb. For that reason, the concept of gandong is not like pela because there is no need for certain agreement among those who have gandong relationship. Because it comes from one mother's womb, then by itself they have the same spirit and spirit to help each other in facing various problems both in difficult and happy. As gandong then they have a different body or physical, but as if it has the same spiritual calling. As gandong, they can be everywhere by professing any religion with whatever profession it does, but among them there is an inner call that they feel themselves. There is no need to go through a customary agreement to unite them. They have been bound from the beginning so that it must be told to the next generation. If there is an agreement between gandong, there may be erroneous acts among the people of their fellow because people in society think that people who committed the offense against gandong as apostates. Therefore, there should be a promise not to repeat apostasy, as well as an effort to eliminate the mistakes that have been made. The gandong relationship has existed since ancestors, where each of them in the bond of gandong retains it and manifests it in various activities to date.

Repetitive events in the form of heat gandong done, actually a means to remind or arouse the spirit brotherhood. This gandong relationship has existed since the ancestors. Each in the bond gandong still maintain it and manifest in various activities to date, among others, in the process of building a building of worship, in the inauguration of the Head of Government Affairs (King), and various other events that are considered to be a burden, must be the joint responsibility of those bound in the bond of gandong.

The Christian Lumoli land Society has a gandong relationship with the people of Luhu land who are Moslems, as well as the people of Lumoli land have a gandong relationship with the people of Christian Affairs Etym. Gandong relationship is embodied in the form of giving responsibility. At the time of construction of the church building in Lumoli land, the people of Hulu land has an obligation to bear the roof of the church. This obligation is done with joy and no burden.

Pela and Gandong to date have proven to be an interesting and important field of study this can be seen with for local researchers (Sahusilawane, 2004; Uneputty, 1996; Lokollo et al., 1997; Ralahallo, 2009; Manuhuttu, 2015; Huwae 1995; Pattiselanno, 1999) but also the concern of national researchers (Hoedodo et al, 2013, Sholeh, 2013) and international (Frost, 2004; Mualim et al., 2014).

The concept of pela and gandong is a strong attribute in reducing poverty in indigenous peoples in Lomoli. This can be seen with the close fraternity between Lumoli villages and some villages with pela and gandong relationships with them. So social issues such as the construction of churches or public places can be solved together. Life is complementary to one another. However, the people have not yet had the strength to develop pela and gandong culture as the basis for networking for poverty alleviation in order for them to live prosperously, as Alexander Laturake acknowledged as one of the key informants that:

The role of gandong associated with poverty alleviation, if maintained it will manifest the attitude of mutual love. We, as villagers, have not got a good way so far, how to use the concept of pela and gandong that has been owned, to open further relationships, in order to conserve the natural wealth that exists in this village for the welfare of children and grandchildren. With the very high expectations the village community can be prosperous in the future. 
These are the hope hope of one of the important figures in Lumoli Village that presents the expectations of the citizens. Lumoli villages have abundant wealth both natural and cultural, but the people still live in distress and poverty. If the concept of pela and gandong is run effectively it will have a great effect for indigenous peoples in Lumoli Village. Pela and gandong (bungso) are built on hereditary bonds which are a very strong brotherhood (Ralahallo, 2012).

\section{CONCLUSION}

So far, the function of Saniri land or leader of clan is less empowered. This can be seen by the appointment of the head of Saniri land directly appointed by the village head rather than the party of certain parties older than Saniri land. The expectations of tua-tua adat saniri are to take into account the background of the people to be proposed in order to have an effect on the future development of the village in relation to the human and cultural development of indigenous peoples. Cultural community is the concept of pela and gandong is a local community culture that is mutually help one another with the community. Life by helping each other is obligatory, not based on coercion but naturally. By applying this concept, decreasing of poverty is expected. The culture of pela and gandong is the basis or path for networking for the eradication of rural poverty in the context of indigenous people. If the concept is well implemented and empowered effectively, it can reduce the poverty rate in the context of indigenous peoples. The implication of this research is to provide a new concept to the community and government in the context of pela and gandong as a good platform to build strong indigenous peoples in alleviating rural poverty.

\section{References}

Adam, J. (2008). Forced Migration, Adat, and A Purified Present In Ambon, Indonesia. Ethnology, 47(4), $227-238$.

Al Qurtuby, S. (2007). Religious and conciliation in Indonesia: Christians and Muslims in the Moluccas. Contemporary Souteast Asia. 39(1), 217-219.

Al Qurtuby, S. (2013). Peacebuilding in Indonesia: Christian-Muslim Alliances in Ambon Island. Journal Islam and Christian-Muslim Relations 24(3), 349-367.

Aspinall, E., \& Mietzner, M. (2007). From Silkworms to Bungled Bailout: International Influences on the 1998 Regime Change in Indonesia. Paper prepared for CDDRL Workshop on External Influences on Democratic Transitions. Stanford University, October 25-26, 2007. 1-44.

Booth, A. (1988). Agricultural Development in Indonesia; Allen and Unwin: Sydney, Australia.

Chen, Z., Liu, C., \& Yang, D. (2011). Information Poverty and Farmers' Information Right in China's Mountainous Rural Areas. Procedia Engineering, 15, 1277-1281.

Colombijn, F. (2018). The Production of Urban Space by Violence and its Aftermath in Jakarta and Kota Ambon, Indonesia. Ethnos Journal of Anthropology, 83(1), 1-22.

Dupont, A. (2000). ASEAN's Response to the East Timor Crisis. Journal Australian Journal of International Affairs, 54(2), 163-170.

Duncan, C. R. (2016). Coexistence not Reconciliation: From Communal Violence to Non-Violence in North Moluccas, Eastern Indonesia. Asia Pacific Journal of Anthropology. 460-474.

Frost, N. (2004). Adat di Maluku: Nilai Baru atau Eksklusivisme Lama? [Custom in Moluccas: New Value or Old Exclusivism?]. Antropologi Indonesia, 74, 1-11.

Goss, J. 2000. Understanding the "Moluccas Wars": Overview of Sources of Communal Conflict and Prospects for Peace. Cakalele, 11, 7-39.

Hagerdal, H. (2015). Eastern Indonesia and the Writing of History. Archipel Études interdisciplinaires sur le monde insulindien, 90. 75-97.

Hoedodo, T.S.B., Surjo, J., Qodir, Z., (2013). Local Political Conflict and Pela Gandong Admist the Religious Conflict. Journal of Government and Politics, 4(2), 336-349.

Kaartinen. (2014). Perceptions of Justice in the Making: Rescaling of Customary Law in PostSuharto Moluccas, Indonesia. Asia Pacific Journal of Anthropology, 15(4), 319-338. 
Leach \& Wood. (2014). The Australia-ASEAN Dialogue: Tracing 40 Years of Partnership: US.Palgrave Macmillan.

Lokollo, J. E., Pattiruhu, C. M., Lestaluhu, M., Timisela, Iz., Limahelu, D., Limahelu, L., Leatemia, J., Leasa G., 1997. Seri Budaya Pela Gandong dari Pulau Ambon. Ambon : Lembaga Kebudayaan daerah Moluccas [Culture Series Pela Gandong from Ambon Island. Ambon: Cultural Institute of Moluccas].

Matesan, I. O. 2018. Organizational Dynamics, Public Condemnation and The Impetus to Disengage from Violence. Terrorism and Political Violence, 1-21.

Manuhutu, R., Purwiyastuti, W., \& Widiarto, T., 2015. Budaya Pela Gandong Di Negeri Haria Sebagai Alat Pemersatu Dan Perdamaian Orang Maluku Tengah [The Culture of Pela Gandong in the Land of Haria as a Unifying and Peaceful Tool of the Central Moluccas]. Widyasari, 17(2), 100-105.

Moxham, B.,\&Carapic, J. 2013. Unravelling Dili: The Crisis of City and State in Timor-Leste. Urban Studies, 50(15), 3116-3133.

Mualim, Awang, J., and Abu Bakar, I., 2014. Pela Gandong Sebagai Pemangkin Toleransi Antara Muslim dan Kristian di Ambon [Pela Gandong as a Tolerant Among Muslims and Christians in Ambon]. Jurnal Hadjari, 6(1), 4355.

Pattiselanno, J. Th. F 1999. Tradisi Uli, Pela dan Gandong pada Masyarakat Seram, Ambon dan Uliase [The tradition of Uli, Pela and Gandong on the Seram, Ambon and Uliase Community]. Antropologi Indonesia, 58, 59-70.

Pessireron, M. F., Loloa, A., \& Eisenring, T. S. S. 2017. The Application of the Functions and the Roles of Tiga Batu Tungku to Solve Social Conflicts of Seram Society in Kamarian Village, Moluccas Province, Indonesia. Mediterranean Journal of Social Sciences, 8(7), 117-122.

Ralahallo, R. N. 2009. Kultur Damai Berbasis Tradisi Pela Dalam Perspektif Psikologis Sosial [Culture of Peace Based on Pela Tradition In Social Psychological Perspective]. Jurnal Psikologi, 36(2), 177-188.

Roling, N., \& van de Fliert, E. 1994. Transforming extension for sustainable agriculture: The case of integrated pest management in Indonesia. Agriculture and Human Values, 11, 96-108.

Sahusilawane, F. 2004. Sejarah Lahirnya Pela dan Gandong Antar Negeri-negeri Di Pulau Ambon. Laporan Penelitian Sejarah dan Nilai Tradisional Ambon. Ambon [History of the Birth of Pela and Gandong Among The Countries On Ambon Island. Historical Research Report and Ambon Traditional Value. Ambon]: Balai Kajian Sejarah dan Nilai Tradisional Ambon.

Sarkar, D.,\&Sengupta, J. 2016. Structural versus nonstructural form of social capital: impact of ethnicity along caste and religious dimensions in Indian context. Asian Ethnicity, 15(1), 78-110.

Schulze, K. E. 2017. The "ethnic" in Indonesia's communal conflicts: violence in Ambon, Poso, and Sambas. Ethnic and Racial Studies. 40(12), 1-19.

Soegijono, S.P. 2015. Papalele: Dangerous Encounter and Transaction in Conflict. Komunitas, 7(2), 297-306.

Sholeh, B. 2013. The Dynamics of Muslim and Christian Relatioins in Ambon, Easter Indonesia. International Journal of Bussines and School Sciences, 4(3), 303-311.

Stott, D. A. Integration and Conflict in Indonesia's Spice Islands. The Asia-Pacific Journal. 15 (11), 3-15.

Tan, L. 2012. Indonesian National Security During The Suharto New Order (1965-1998): The Role of Narratives of Peoplehood and The Construction of Danger. New Zealand Journal of Asian Studies, 14(1), 49-70.

Tatyzo, C. 2011. Nia Dinata and Indonesia's post-New Order Film Culture. Asia Online Flinders Asia Centre Occasional Paper 3, May 2011. 1-42.

Titahelu, J. A. S.., Irwansyah., Awaludi, H., \& Ashari, M. 2015. Strengthening Pela-Gandong Alliance Based on John Rawls' Theory of Justice. Hasanudin Law Review, 1(3), 417-429.

Waileruny, S. 2010. Membongkar Konspirasi di Balik Konflik Maluku [Dismantling the Conspiracy behind the Moluccan Conflict], Yayasan Obor: Indonesia.

Wilson, C. 2015. Illiberal democracy and violent conflict in contemporary Indonesia. Journal Democratization 22(7), 1-21. 